\title{
Efficacy of Herbicide Mixtures on Yield and Yield Attributes in Wet Direct Seeded Rice
}

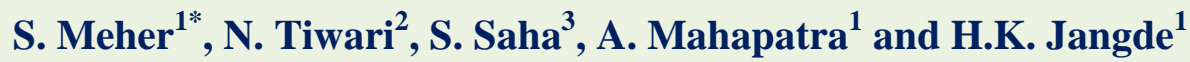 \\ ${ }^{1}$ Department of Agronomy, I.G.K.V., Raipur, Chhattisgarh-492012, India \\ ${ }^{2}$ Department of Agronomy, I.G.K.V., Raipur, India \\ ${ }^{3}$ NRRI, Cuttack, Odisha-753006, India \\ *Corresponding author
}

\begin{tabular}{|l|}
\hline K e y w o r d s \\
Direct seeded rice, \\
Herbicide mixtures, \\
Yield, Yield \\
attributes
\end{tabular}

\section{A B S T R A C T}

Direct seeded rice having weed diversity in a substantial amount and the use of single herbicide for weed management is ineffective to control the wide range of weed hence chances of weed flora shift and herbicide resistance in weeds is expected. So to study the efficacy of herbicide mixtures in wet direct seeded rice, an experiment was conducted at Institute Research Farm of ICAR-National Rice Research Institute, Cuttack (Odisha) during kharif season of 2017. The test rice variety was 'CR Dhan 203'and the experiment was laid out in Randomized Block Design (RBD) with three replications and twelve treatments viz. nine herbicide mixtures (Azimsulfuron $50 \% \mathrm{DF}+$ Bispyribac sodium $10 \%$ SC @ (22+25) $\mathrm{g} \mathrm{ha}^{-1}\left(\mathrm{~T}_{1}\right)$, Flucetosulfuron 10\% WDG $(\mathrm{w} / \mathrm{w})+$ Bispyribac sodium $10 \% \mathrm{SC}$ @(25+25) $\mathrm{g} \mathrm{ha}^{-1}\left(\mathrm{~T}_{2}\right)$, Penoxsulam 21.7\% SC+ Cyhalofop-butyl 12\% EC (w/v) @ $(25+100) \mathrm{g} \mathrm{ha}^{-1}\left(\mathrm{~T}_{3}\right)$, Fenoxaprop-p ethyl 6.7\% EC (w/w) + Ethoxysulfuron 15\% WDG (w/w)@(50+15) $\mathrm{g} \mathrm{ha}^{-1}\left(\mathrm{~T}_{4}\right)$, Bispyribac sodium 10\% SC + Ethoxysulfuron 15\% WDG (w/w) @ (25+15) g ha ${ }^{-1}\left(\mathrm{~T}_{5}\right)$, Cyhalofop-butyl 12\% EC (w/v) + Ethoxysulfuron 15\% WDG (w/w)@ (75+15) $\mathrm{g} \mathrm{ha}^{-1}\left(\mathrm{~T}_{6}\right)$, XR 848 (benzyl ester) $2.5 \%$ EC (w/v) + Cyhalofop-butyl 12\% EC (w/v) @ (25+100) $\mathrm{g} \mathrm{ha}^{-1}\left(\mathrm{~T}_{7}\right)$, Flucetosulfuron 10\% WDG (w/w) + Pretilachlor $30.7 \%$ EC @ (25+500) $\mathrm{g} \mathrm{ha}^{-1}\left(\mathrm{~T}_{8}\right)$, Bensulfuron methyl 0.7\% + Pretilachlor 7\% GR @ $\left.(70+700) \mathrm{g} \mathrm{ha}^{-1}\left(\mathrm{~T}_{9}\right)\right)$, single herbicide Bispyribac sodium 10\% SC @ $30 \mathrm{~g} \mathrm{ha}^{-1}\left(\mathrm{~T}_{10}\right)$, weed free $\left(T_{11}\right)$ and weedy check $\left(T_{12}\right)$. Result was found that among the weed management treatments, the weed free treatment $\left(\mathrm{T}_{11}\right)$ registered significantly highest value and was at par with Fenoxaprop-p ethyl 6.7\% EC (w/w) + Ethoxysulfuron 15\% WDG (w/w) @ $(50+15) \mathrm{g} \mathrm{ha}^{-1}\left(\mathrm{~T}_{4}\right)$ regarding yield and yield attributes like effective tillers $\mathrm{m}^{-2}$ and panicle weight, number of grains panicle ${ }^{-1}$, number of filled grains panicle ${ }^{-1}$, grain and straw yield, whereas the effects of the treatment remained non-significant in test weight and harvest index.

\section{Introduction}

Rice (Oryza sativa L.) has shaped the culture, diets and economics of thousand of millions of peoples. For more than half of the humanity "rice is life." In recent years, manual transplantation in many Asia countries has been replaced by MTR (Machine Transplanted Rice) and DSR (Direct Seeded Rice) as a response to the increasing costs of labour 
and/or water (Watanabe, 2011, Matloob et al., 2015) and (Pandey and Velasco, 2005) But weeds are one of the major biotic constraints in rice production, particularly in DSR and in the absence of any control measures may range from 10 to $100 \%$ (Rao et al., 2007).

Weed management in rice for much of Asia (particularly South Asia) relies on hand weeding, in addition to herbicides (Watanabe, 2011, Kraehmer et al., 2016. Wide ranges of herbicides are available for the management of grassy weeds as well as broad-leaved weeds.

Repeated and injudicious use of same herbicide or herbicides having similar mechanism of action may lead to shift of weed flora, development of herbicide resistance and build-up of herbicide load in the environment (Das and Duary, 1999, Duary, 2008).

Since, DSR fields are characterized by floristically diverse weed communities (Rao et al., 2007), So, herbicide combinations or mixtures acting as promising major strategy to prevent shift of weed flora and development of herbicide resistance in weeds.

More recently use of mixture herbicides is increasing due to the benefits of managing complex weed flora with mixture- either tank or ready mix. Avudaithai and Veerabadran (2000) reported that even at lower doses proved more effective to control against a broad spectrum of weeds.

Ready mix product of bensulfuron methyl + pretilachlor at $60+600 \mathrm{~g} / \mathrm{ha}$ and tank mixed application of azimsulfuron + chlorimuronethyl or metsulfuron-methyl, bispyribac + almix, fenoxaprop-p ethyl + ethoxysulfuron has also been found quite effective against complex weed flora (Jayadeva et al., 2011) and for better weed control efficiency against broadleaved and sedges as compared to grasses (Saha and Rao 2009).

\section{Materials and Methods}

The experimental site was located at the Institute Research Farm of ICAR-National Rice Research Institute, Cuttack (Odisha), in 2017 where adequate facilities for irrigation and drainage exist. The meteorological data, recorded during experimental period showed that crop received $990.71 \mathrm{~mm}$ rainfall during the crop period. The soil of the experimental field was sandy clay loam in texture. The soil was neutral in reaction. It had low nitrogen, medium phosphorus and high potassium contents. The experiment was laid out in randomized complete block design (RBD) with three replications. The net plot size was $5.8 \mathrm{~m} \times 3.8 \mathrm{~m}\left(22.04 \mathrm{~m}^{2}\right)$. There were twelve treatments of post emergence herbicides and herbicide mixtures in different doses along with hand weeding and untreated control (weedy check) for direct seeded rice.

Herbicide molecules bearing Azimsulfuron $50 \%$ DF+ Bispyribac sodium 10\% SC @ $(22+25) \mathrm{g} \mathrm{ha}^{-1}\left(\mathrm{~T}_{1}\right) \quad(\mathrm{AZM}+\mathrm{BSP})$, Flucetosulfuron 10\% WDG (w/w) + Bispyribac sodium 10\% SC @ $(25+25) \mathrm{g} \mathrm{ha}^{-1}$ $\left(\mathrm{T}_{2}\right)$ (FCS+ BSP), Penoxsulam 21.7\% SC+ Cyhalofop-butyl 12\% EC (w/v) @ (25+100) g ha $^{-1}\left(\mathrm{~T}_{3}\right)(\mathrm{PNX}+\mathrm{ES})$, Fenoxaprop-p ethyl $6.7 \%$ EC (w/w) + Ethoxysulfuron 15\% WDG (w/w)@(50+15) g ha-1 $\left(\mathrm{T}_{4}\right)$ (FPE+ ES), Bispyribac sodium 10\% SC + Ethoxysulfuron $15 \%$ WDG (w/w) @ (25+15) g ha ${ }^{-1}\left(\mathrm{~T}_{5}\right)$ (BSP+ ES), Cyhalofop-butyl 12\% EC (w/v) + Ethoxysulfuron 15\% WDG (w/w) @ (75+15) $\mathrm{g} \mathrm{ha}^{-1}\left(\mathrm{~T}_{6}\right)(\mathrm{CHB}+\mathrm{ES})$, XR 848 (benzyl ester) $2.5 \% \mathrm{EC}(\mathrm{w} / \mathrm{v})+$ Cyhalofop-butyl 12\% EC $(\mathrm{w} / \mathrm{v}) @(25+100) \mathrm{g} \mathrm{ha}^{-1}\left(\mathrm{~T}_{7}\right) \quad(\mathrm{XR}-848+$ CHB), Flucetosulfuron 10\% WDG (w/w) + Pretilachlor 30.7\% EC @ (25+500) g ha-1 $\left(\mathrm{T}_{8}\right)$ (FCS+ PTCL), Bensulfuron methyl 0.7\%+ Pretilachlor 7\% GR @ (70+700) g ha-1 $\left(\mathrm{T}_{9}\right)$ (BSM+ PTCL), Bispyribac sodium 10\% SC @ $30 \mathrm{~g} \mathrm{ha}^{-1}\left(\mathrm{~T}_{10}\right)$ (BSP) with above mentioned time are applied to evaluate the efficacy of 
newly standardized herbicide mixtures for broad spectrum and cost effective weed control in wet direct seeded rice.

\section{Results and Discussion}

Number of effective tillers $\mathbf{m}^{-2}$

Data with respect to number of effective tillers $\mathrm{m}^{-2}$ are presented in Table 1. Among different treatments, the weed free plot $\left(\mathrm{T}_{11}\right)$ produced maximum number of effective tillers $(385.00$ $\mathrm{m}^{-2}$ ) which is at par with Fenoxaprop-p ethyl $6.7 \% \mathrm{EC}(\mathrm{w} / \mathrm{w})+$ Ethoxysulfuron $15 \%$ WDG (w/w)@(50+15) g ha $\mathrm{g}^{-1}\left(\mathrm{~T}_{4}\right)$, Penoxsulam $21.7 \%$ SC+ Cyhalofop-butyl 12\% EC (w/v) @ $(25+100) \mathrm{g} \mathrm{ha}^{-1}\left(\mathrm{~T}_{3}\right)$, Flucetosulfuron $10 \%$ WDG (w/w) + Bispyribac sodium 10\% SC @ $(25+25) \mathrm{g} \mathrm{ha}^{-1}\left(\mathrm{~T}_{2}\right)$, Azimsulfuron $50 \% \mathrm{DF}+$ Bispyribac sodium 10\% SC @ $(22+25) \mathrm{g} \mathrm{ha}^{-1}$ $\left(\mathrm{T}_{1}\right)$, Bispyribac sodium $10 \% \quad \mathrm{SC}+$ Ethoxysulfuron 15\% WDG (w/w) @ (25+15) $\mathrm{g} \mathrm{ha}^{-1}\left(\mathrm{~T}_{5}\right)$. The lowest number of effective tillers were produced by the untreated weedy check $\left(T_{12}\right) \quad\left(196.00 \mathrm{~m}^{-2}\right)$ followed by Bispyribac sodium 10\% SC @ $30 \mathrm{~g} \mathrm{ha}^{-1}\left(\mathrm{~T}_{10}\right)$ $\left(271.00 \mathrm{~m}^{-2}\right)$.

\section{Number of grains panicle ${ }^{-1}$}

Data regarding number of grains (panicle ${ }^{-1}$ ), as influenced by different treatments are presented in Table 1. The highest number of grains were found to be in weed free plot $\left(\mathrm{T}_{11}\right)$ (137.86 panicle $^{-1}$ ) which was at par with Fenoxaprop-p ethyl $6.7 \%$ EC (w/w) + Ethoxysulfuron 15\% WDG (w/w) @ (50+15) g ha $\mathrm{ha}^{-1} \quad\left(\mathrm{~T}_{4}\right), \quad$ Penoxsulam $21.7 \%$ SC+Cyhalofop-butyl $12 \% \quad$ EC $\quad(w / v) \quad @$ $(25+100) \mathrm{g} \mathrm{ha}^{-1}\left(\mathrm{~T}_{3}\right)$, Flucetosulfuron $10 \%$ WDG (w/w) + Bispyribac sodium 10\% SC @ $(25+25) \mathrm{g} \mathrm{ha}^{-1}\left(\mathrm{~T}_{2}\right)$, Azimsulfuron $50 \% \mathrm{DF}+$ Bispyribac sodium 10\% SC @ $(22+25) \mathrm{g} \mathrm{ha}^{-1}$ $\left(\mathrm{T}_{1}\right)$. The lowest grains panicle ${ }^{-1}$ was obtained under untreated weedy check $\left(\mathrm{T}_{12}\right)$ i.e. $(101.00$ panicle $^{-1}$ ). The higher number of grain pancle ${ }^{-1}$ recorded in these treatments might be due to lower weed competition in terms of dry matter of weeds which created an overall favourable environment for growth and development of rice resulting more availability of light, moisture, nutrients and space for rice plant which led to produce more number of grains panicle $^{-1}$.

\section{Number of filled grains panicle ${ }^{-1}$}

Data regarding number of filled grains $\left(\right.$ panicle $^{-1}$ ) are presented in Table 1 from which it can be observed that the different weed management practices had significant effect on this yield attributing character. The highest number of filled grains were obtained in weed free $\left(\mathrm{T}_{11}\right)\left(109.93\right.$ panicle $\left.^{-1}\right)$ which was at par Fenoxaprop-p ethyl 6.7\% EC (w/w) + Ethoxysulfuron 15\% WDG (w/w) @ $(50+15) \mathrm{g} \mathrm{ha}^{-1}\left(\mathrm{~T}_{4}\right)$, Penoxsulam $21.7 \% \mathrm{SC}+$ Cyhalofop-butyl 12\% EC (w/v) @ (25+100) g ha $^{-1}\left(\mathrm{~T}_{3}\right)$, Azimsulfuron $50 \% \mathrm{DF}+$ Bispyribac sodium 10\% SC @ $(22+25) \mathrm{g} \mathrm{ha} \mathrm{h}^{-1}\left(\mathrm{~T}_{1}\right)$, Flucetosulfuron $10 \%$ WDG (w/w) + Bispyribac sodium 10\% SC @ $(25+25) \mathrm{g} \mathrm{ha}^{-1}$ $\left(\mathrm{T}_{2}\right)$. The weedy check $\left(\mathrm{T}_{12}\right)\left(72.27\right.$ panicle $\left.^{-1}\right)$ produced the lowest number of filled grains panicle $^{-1}$.

\section{Number of unfilled grains panicle ${ }^{-1}$}

Data regarding number of unfilled grains $\left(\right.$ panicle $^{-1}$ ) are presented in Table 1 which shows that the different treatments influenced the character significantly. It was highest in untreated weedy check $\left(T_{12}\right)\left(29.73\right.$ panicle $\left.^{-1}\right)$ and all the treatments were at par with wed free $\left(T_{11}\right)$ (17.93 panicle $\left.{ }^{-1}\right)$. However, it was lowest in Cyhalofop-butyl 12\% EC (w/v) + Ethoxysulfuron 15\% WDG (w/w) @ (75+15) $\mathrm{g} \mathrm{ha}^{-1}\left(\mathrm{~T}_{6}\right)\left(15.86\right.$ panicle $\left.^{-1}\right)$. Due to more competition between crop and weed there might be less availability of resources like moisture, nutrients, light and space, which led to less translocation of photosynthates from source to sink resulting higher number of unfilled grains panicle ${ }^{-1}$ in weedy check $\left(\mathrm{T}_{12}\right)$. 
Table.1 Yield attributing characters at different periods of plant growth as influenced by different herbicide mixtures in wet seeded rice

\begin{tabular}{|c|c|c|c|c|c|c|c|}
\hline \multirow{2}{*}{\multicolumn{2}{|c|}{ Treatments }} & \multirow{3}{*}{$\begin{array}{l}\text { Dose } \\
\left(\mathrm{g} \mathrm{ha}^{-1}\right) \\
22+25\end{array}$} & \multicolumn{5}{|c|}{ Yield attributing characters } \\
\hline & & & \multirow{2}{*}{$\begin{array}{l}\text { No. of } \\
\text { effective } \\
\text { tillers }\left(\mathbf{m}^{-2}\right) \\
343.00\end{array}$} & \multirow{2}{*}{$\begin{array}{l}\text { No. of } \\
\text { grains } \\
\text { panicle }^{-1} \\
123.65\end{array}$} & \multirow{2}{*}{$\begin{array}{l}\text { No. of } \\
\text { filled } \\
\text { grains } \\
107.01\end{array}$} & \multirow{2}{*}{$\begin{array}{l}\text { No. of } \\
\text { unfilled } \\
\text { grains } \\
16.64\end{array}$} & \multirow{2}{*}{$\begin{array}{l}\text { Sterility } \\
\% \\
13.45\end{array}$} \\
\hline $\mathrm{T}_{1}$ & $\mathrm{AZM}+\mathrm{BPS}$ & & & & & & \\
\hline $\mathbf{T}_{2}$ & $\mathrm{FCS}+\mathrm{BPS}$ & $25+25$ & 334.00 & 120.66 & 104.13 & 16.53 & 13.69 \\
\hline $\mathbf{T}_{\mathbf{3}}$ & $\mathrm{PNX}+\mathrm{CHB}$ & $25+100$ & 348.00 & 125.81 & 108.93 & 16.88 & 13.41 \\
\hline$\overline{T_{4}}$ & $\mathrm{FPE}+\mathrm{ES}$ & $50+15$ & 358.67 & 130.45 & 113.22 & 17.23 & 13.25 \\
\hline $\mathbf{T}_{5}$ & $\mathrm{BPS}+\mathrm{ES}$ & $25+15$ & 327.67 & 117.67 & 101.45 & 16.22 & 13.78 \\
\hline $\mathrm{T}_{6}$ & $\mathrm{CHB}+\mathrm{ES}$ & $75+15$ & 292.00 & 109.02 & 93.16 & 15.86 & 14.54 \\
\hline$\overline{T_{7}}$ & XR- $848+\mathrm{CHB}$ & $25+100$ & 308.33 & 114.87 & 98.66 & 16.21 & 14.11 \\
\hline $\mathrm{T}_{8}$ & FCS+ PTCL & $25+500$ & 299.33 & 112.11 & 95.92 & 16.19 & 14.44 \\
\hline$\overline{T_{9}}$ & BSM+ PTCL & $70+700$ & 288.67 & 108.06 & 91.56 & 16.49 & 15.26 \\
\hline$T_{10}$ & BPS & 30 & 271.00 & 106.27 & 89.95 & 16.32 & 15.35 \\
\hline $\mathbf{T}_{11}$ & Weed free & & 385.00 & 137.86 & 119.93 & 17.93 & 13.08 \\
\hline$\overline{T_{12}}$ & Weedy check & & 196.00 & 101.00 & 72.27 & 29.73 & 29.43 \\
\hline \multicolumn{2}{|c|}{ SEm \pm} & & 25.07 & 6.88 & 5.43 & 1.29 & 1.04 \\
\hline \multicolumn{2}{|c|}{$\mathrm{CD}(\mathrm{P}=0.05)$} & & 73.54 & 20.18 & 15.94 & 3.99 & 2.78 \\
\hline
\end{tabular}

Table.2 Test weight (g), Grain yield $\left(\mathrm{t} \mathrm{ha}^{-1}\right)$, Straw yield $\left(\mathrm{t} \mathrm{ha}^{-1}\right)$, and Harvest index $(\%)$ at different periods of plant growth as influenced by different herbicide mixtures in wet direct seeded rice

\begin{tabular}{|l|l|l|l|l|l|l|}
\hline Treatments & $\begin{array}{l}\text { Dose } \\
\left(\mathrm{g} \mathrm{ha}^{-1}\right)\end{array}$ & $\begin{array}{l}\text { Test weight } \\
(\mathrm{g})\end{array}$ & $\begin{array}{l}\text { Grain yield } \\
\left(\mathbf{t ~ h}^{-1}\right)\end{array}$ & $\begin{array}{l}\text { Straw yield } \\
\left(\mathbf{t} \mathbf{h a}^{-1}\right)\end{array}$ & $\begin{array}{l}\text { Harvest } \\
\text { Index }(\%)\end{array}$ \\
\hline $\mathrm{T}_{1}$ & AZM + BPS & $22+25$ & 22.72 & 4.68 & 5.10 & 47.85 \\
\hline $\mathrm{T}_{2}$ & FCS + BPS & $25+25$ & 22.08 & 4.57 & 4.99 & 47.82 \\
\hline $\mathrm{T}_{3}$ & PNX+CHB & $25+100$ & 22.40 & 4.75 & 5.17 & 47.87 \\
\hline $\mathrm{T}_{4}$ & FPE +ES & $50+15$ & 23.19 & 4.88 & 5.32 & 47.88 \\
\hline $\mathrm{T}_{5}$ & BPS+ ES & $25+15$ & 22.54 & 4.46 & 4.88 & 47.73 \\
\hline $\mathrm{T}_{6}$ & CHB +ES & $75+15$ & 21.26 & 3.98 & 4.38 & 47.62 \\
\hline $\mathrm{T}_{7}$ & XR -848 + CHB & $25+100$ & 21.80 & 4.20 & 4.61 & 47.69 \\
\hline $\mathrm{T}_{8}$ & FCS+ PTCL & $25+500$ & 21.32 & 4.07 & 4.47 & 47.68 \\
\hline $\mathrm{T}_{9}$ & BSM+PTCL & $70+700$ & 22.13 & 3.93 & 4.32 & 47.61 \\
\hline $\mathrm{T}_{10}$ & BPS & 30 & 20.68 & 3.76 & 4.14 & 47.60 \\
\hline $\mathrm{T}_{11}$ & Weed free & & 23.87 & 5.23 & 5.69 & 47.88 \\
\hline $\mathrm{T}_{12}$ & Weedy check & & 20.12 & 2.81 & 3.09 & 47.59 \\
\hline SEm \pm & & 1.23 & 0.33 & 0.34 & 0.09 \\
\hline CD $(\mathbf{P}=0.05)$ & & 3.62 & 0.97 & 1.00 & NS \\
\hline
\end{tabular}




\section{Sterility percentage}

From the data presented in Table 1 it can be concluded that different weed management practices had significant influence on sterility percentage. As sterility percentage is a function of total number of grains panicle ${ }^{-1}$ and number of sterile grains panicle ${ }^{-1}$, among the weed management practices, significantly higher number of sterile grains were obtained from the untreated weedy check $\left(\mathrm{T}_{12}\right)(29.43$ $\%)$. The highest reduction in sterility percentage of rice was observed with the weed free $(13.08 \%)$ which was at par with rest treatments.

\section{Test weight (g)}

Data with respect to test weight are presented in Table 2 which shows that the different weed management practices did not influence the test weight significantly. However the highest test weight was obtained in weed free $\left(\mathrm{T}_{11}\right)$ (23.87) and it was at par with all the treatments except weedy check $\left(\mathrm{T}_{12}\right)$ (20.12).

\section{Grain yield $\left(\mathrm{t} \mathrm{ha}^{-1}\right)$}

Data with respect to grain yield is presented in Table 2. It is clear from the data that the different weed management treatments significantly influenced the grain yield. Among different treatments, the weed free $\left(\mathrm{T}_{11}\right) \quad\left(5.23 \mathrm{t} \mathrm{ha}^{-1}\right)$ proved significantly superior producing higher grain yield, but it was found at par with v Fenoxaprop-p ethyl 6.7\% EC (w/w) + Ethoxysulfuron 15\% WDG (w/w) @(50+15) $\mathrm{g} \mathrm{ha}^{-1}\left(\mathrm{~T}_{4}\right)$, Penoxsulam $21.7 \%$ SC+ Cyhalofop-butyl 12\% EC (w/v) @ (25+100) $\mathrm{g} \mathrm{ha}^{-1}\left(\mathrm{~T}_{3}\right)$, Flucetosulfuron 10\% WDG (w/w) + Bispyribac sodium 10\% SC @ $(25+25) \mathrm{g} \mathrm{ha}^{-1}\left(\mathrm{~T}_{2}\right)$, Azimsulfuron $50 \% \mathrm{DF}+$ Bispyribac sodium 10\% SC @ $(22+25) \mathrm{g} \mathrm{ha}^{-1}$ $\left(\mathrm{T}_{1}\right)$, Bispyribac sodium $10 \% \mathrm{SC}+$ Ethoxysulfuron 15\% WDG (w/w) @ (25+15) $\mathrm{g} \mathrm{ha}^{-1}\left(\mathrm{~T}_{5}\right)$. Timely and effective control of weeds during the critical crop-weed competition period with use of postemergence herbicides resulted in increased yield components, which ultimately reflected on grain yield. Lower weed population and higher weed control efficiency also contributed to higher grain yield.

\section{Straw yield $\left(\mathrm{t} \mathrm{ha} \mathbf{~}^{-1}\right)$}

The data on straw yield is presented in Table 2 which indicates that the treatments significantly influenced it. And it follows the same order as grain yield. The weed free plot $\left(\mathrm{T}_{11}\right)$ produced highest amount of straw (5.69 $\mathrm{t} \mathrm{ha}^{-1}$ ) which was at par with the same herbicides mixtures as per grain yield. Among the herbicide treatments, the untreated weedy check $\left(\mathrm{T}_{12}\right)\left(3.09 \mathrm{t} \mathrm{ha}^{-1}\right)$ yielded the lowest amount of straw.

\section{Harvest index (\%)}

The data regarding harvest index is presented in Table 2 which indicate that the treatments did not influence the harvest index significantly. However the weed free plot $\left(\mathrm{T}_{12}\right)(47.89 \%)$ followed by herbicide mixture Fenoxaprop-p ethyl 6.7\% EC (w/w) + Ethoxysulfuron 15\% WDG (w/w) @ (50+15) g ha ${ }^{-1}\left(\mathrm{~T}_{4}\right)$, Penoxsulam 21.7\% $\mathrm{SC}+$ Cyhalofop-butyl 12\% EC (w/v) @ (25+100) g ha $^{-1}\left(\mathrm{~T}_{3}\right)$, Flucetosulfuron $10 \%$

WDG (w/w) + Bispyribac sodium 10\% SC @ $(25+25) \mathrm{g} \mathrm{ha}^{-1}\left(\mathrm{~T}_{2}\right)$, Azimsulfuron $50 \% \mathrm{DF}+$ Bispyribac sodium 10\% SC @ $(22+25) \mathrm{g} \mathrm{ha}^{-1}$ $\left(\mathrm{T}_{1}\right)$, Bispyribac sodium $10 \% \quad \mathrm{SC}+$ Ethoxysulfuron 15\% WDG (w/w) @ (25+15) $\mathrm{g} \mathrm{ha}^{-1}\left(\mathrm{~T}_{5}\right)$ and was found lowest in weedy check $\left(\mathrm{T}_{12}\right)$.

The results of this experiment revealed that among the herbicide treatments Fenoxapropp-ethyl + Ethoxysulfuron @ $(50+15) \mathrm{g} \mathrm{ha}^{-1}$ $\left(\mathrm{T}_{4}\right)$ recorded highest yield attributes i.e 
number of effective tillers, grains per panicle, filled and unfiled grains per panicle, grain and straw yield, harvest index and registered lowest regarding sterility percentage which was at par with Penoxulam+Cyhalofop butyl $@(25+100) \mathrm{g} \mathrm{ha}^{-1}\left(\mathrm{~T}_{3}\right)$, Azimsulfuron $50 \%$ DF+ Bispyribac sodium 10\% SC @ $(22+25) \mathrm{g}$ ha $^{-1}\left(\mathrm{~T}_{1}\right)$, Flucetosulfuron $10 \%$ WDG $(\mathrm{w} / \mathrm{w})+$ Bispyribac sodium 10\% SC @ (25+25) $\mathrm{g} \mathrm{ha}^{-1}$ $\left(\mathrm{T}_{2}\right)$, Bispyribac sodium $10 \% \mathrm{SC}+$ Ethoxysulfuron 15\% WDG (w/w) @ (25+15) $\mathrm{g} \mathrm{ha}^{-1}\left(\mathrm{~T}_{5}\right)$ except in case of filled and unfilled grains per panicle where $\left(T_{4}\right)$ was at par with all the herbicide treatments. Hence herbicide mixtures is a reliable and reasonable option for effective weed management in direct seeded rice.

\section{References}

Avudaithai, S. and Veerabadran, V. 2000. Effect of herbicide mixtures on the total weed spectrum in transplanted rice. Crop Research, 19: 6-12.

Das, T.K. and Duary, B. 1999. Herbicide resistance in weeds: current scenario, mechanisms and management strategies for now and future. Annals of Agricultural Research, 20:393-398.

Duary, B. 2008. Recent advances in herbicide resistance in weeds and its management. Indian Journal of Weed Science, 40 (3\&4):124-135.

Jayadeva, H.M., Bhairappanavar, S.T., Hugar, A.Y., Rangaswamy, B.R., Mallikarjun, G.B., Malleshappa, C. and Naik, D.C.
2011. Integrated weed management in aerobic rice (Oryza sativa L.). Agricultural Science Digest, 31: 58-61.

Kraehmer, H., K. Jabran, H. Mennan, and B.S. Chauhan. 2016. Global distribution of rice weeds-A review. Crop Prot. 80:73-86.

Matloob, A., Khaliq, A. and Chauhan, B.S. 2015. Weeds of direct-seeded rice in Asia: problems and opportunities. Advances in Agronomy, 130: 291-336.

Moody, K. 1993. Weed control in wet-seeded rice. Experimental Agriculture, 29: 393403.

Pandey, S. and Velasco, L. 2005. Trends in crop establishment methods in Asia and research issues. In: Rice is Life: Scientific Perspectives for the 21st Century, Proceedings of the World Rice Research Conference, 4-7 November 2004, Tsukuba, Japan, pp. 178-181.

Rao, A.N., Johnson, D.E., Sivaprasad, B., Ladha, J.K. and Mortimer, A.M. 2007. Weed management in direct-seeded rice. Advances in Agronomy, 93: 153255.

Saha, S and Rao, K.S. 2009. Efficacy of sulfonyl urea herbicides for broad spectrum weed control in wet direct sown summer rice. Oryza, 46 (2): 116119.

Watanabe, H. 2011. Development of lowland weed management and weed succession in Japan. Weed Biology and Management, 11:175-189.

\section{How to cite this article:}

Meher, S., Tiwari, N., Saha, S., Mahapatra, A., Jangde, H.K. 2018. Efficacy of Herbicide Mixtures on Yield and Yield Attributes in Wet Direct Seeded Rice. Int.J.Curr.Microbiol.App.Sci. 7(07): 4071-4076. doi: https://doi.org/10.20546/ijcmas.2018.707.473 